IARG

Laboratoire

de Recherche

en Gestion

\& Economie

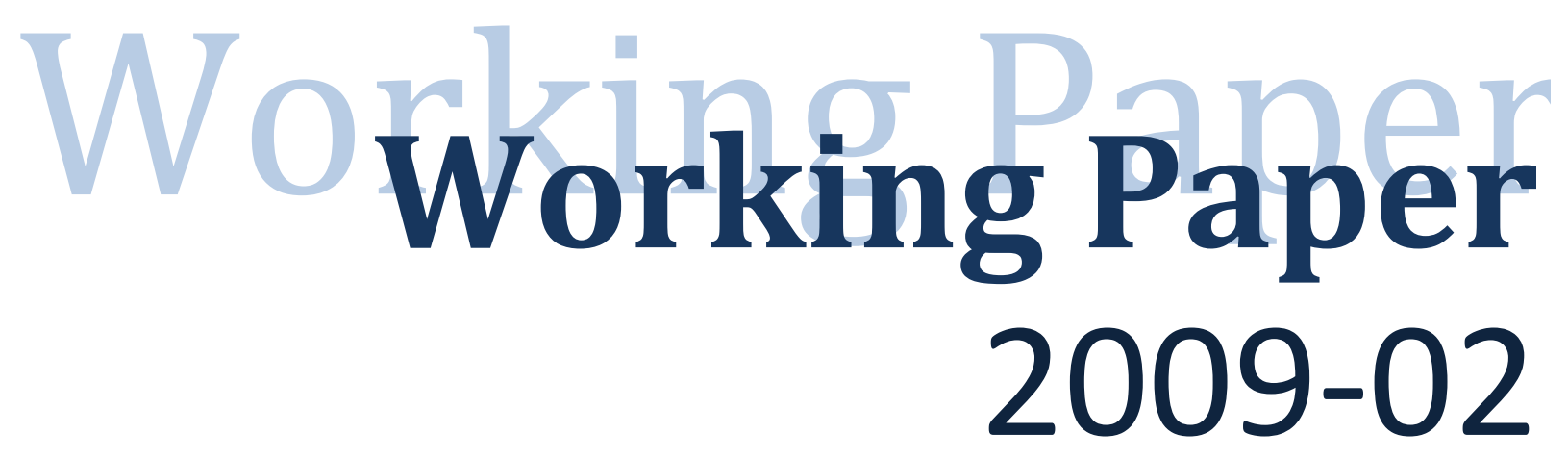

Do Islamic Banks Have Greater Market Power?

\author{
Laurent Weill
}

February 2009

Ecole de Management Strasbourg Pôle Européen de Gestion et d'Economie 61 avenue de la Forêt Noire 67085 Strasbourg Cedex 


\title{
Do Islamic Banks Have Greater Market Power?
}

This version: February 2009

\author{
Laurent Weill ${ }^{1}$ \\ University of Strasbourg and EM Strasbourg Business School \\ LARGE, 47 avenue de la Forêt Noire \\ 67000 Strasbourg \\ e-mail: laurent.weill@unistra.fr
}

\footnotetext{
${ }^{1}$ I would like to thank Christophe Godlewski for his help.
} 


\title{
Do Islamic Banks Have Greater Market Power?
}

This version: February 2009

\begin{abstract}
$\underline{\text { Abstract }}$
The aim of this paper is to investigate whether Islamic banks have greater market power than conventional banks. Indeed Islamic banks may benefit from a captive clientele, owing to religious principles, which would be charged greater prices. To measure market power, we compute Lerner indices on a sample of banks from 17 countries in which Islamic and conventional banks coexist over the period 2000-2007. Comparison of Lerner indices shows no significant difference between Islamic banks and conventional banks. When including control variables, regression of Lerner indices even suggests that Islamic banks have a lower market power than conventional banks. A robustness check with the Rosse-Panzar model confirms that Islamic banks are not less competitive than conventional banks. The lower market power of Islamic banks can be explained by their different norms and their different incentives.
\end{abstract}

JEL Codes: G21, D43, D82.

Keywords: Islamic banks, Lerner index, Bank Competition. 


\section{Introduction}

There is a wide expansion of Islamic banks in the recent decades. Since the creation of the first modern Islamic bank in 1975, the number of these institutions has increased to over 300 operating in more than 75 countries. Total assets of Islamic banks worldwide are estimated at about 300 billion USD with an annual growth rate of more than 15\% over the last decade (Chong and Liu, 2009). ${ }^{2}$

Despite this considerable development, the academic literature - though increasing remains scarce on the economic implications of Islamic banking in comparison with conventional banking. Indeed it is of utmost interest to know whether Islamic banks may differ than conventional banks for economic issues, and may therefore foster or hamper economic development in comparison to conventional banks.

In this area, a key question concerns the market power of Islamic banks. Market power is the ability of a firm to influence the price of products and is therefore directly linked to competition, as greater competition reduces market power. Islamic banks may have a greater market power than conventional banks. Indeed they can benefit from a clientele with a more inelastic demand, coming from religious principles. Most countries with Islamic banks have the ongoing presence of few Islamic banks with conventional banks. Therefore, religious clients may be more captive to Islamic banks following their will to respect the Shariah, than non-religious clients to all categories of banks. El Gamal (2007) mentions that some providers and observers of the Islamic banking industry refer to these additional charges and rates for clients of Islamic banks as "the cost of being Muslim", and stresses the possibility of such overpricing. ${ }^{3}$ Kuran (2004) supports this view by observing that Turkish banks managed to attract quickly one percent of total deposits in a few months, in spite of a small number of branches.

The comparative analysis of market power between Islamic and conventional banks is a fundamental issue for economic development, as several studies have shown the importance of market power for economic development (Petersen and Rajan, 1995; Jayaratne and Strahan, 1996; Cetorelli and Gambera, 2001). In a nutshell, the argument is that greater bank competition enhances access to credit at lower cost that leads to more borrowing for firms, which promotes growth. More generally, an enhancement of bank competition can favor financial development by increasing access to financial products and, as literature has shown

\footnotetext{
${ }^{2}$ For a complete reference on Islamic banking, see Iqbal and Mirakhor (2007).

${ }^{3}$ In an interview, El-Gamal indeed argues that he worries about the possibility that "some sectors of the Muslim American population might be willing to pay $\$ 500$ more to buy peace of mind”. (http://www.universityislamicfinancial.com/file/News/Voiceof\%20AmericaArticle\%2004.09.2007l.pdf)
} 
a positive link between financial development and economic development (Levine, 2005), then contributes to foster economic development.

The aim of this research is therefore to measure and compare the market power of Islamic banks and conventional banks. To do so, we compute Lerner indices on a wide crosscountry sample of banks from 17 MENA and Southeastern Asian countries, in which Islamic banks and conventional banks coexist, over the period 2000-2007. The Lerner index equals the price minus the marginal cost, divided by the price. It has been widely used in recent studies focusing on market power in banking (Fernandez de Guevara, Maudos and Perez, 2005; Fernandez de Guevara and Maudos, 2007; Solis and Maudos, 2008).

To our knowledge, no empirical work has ever investigated this issue. Nevertheless, a couple of papers can be loosely related to our work, as they also provide elements of comparison between Islamic and conventional banks through empirical works at the bank level. In their analysis of efficiency of Turkish banks for the period 1990-2000, El-Gamal and Inanoglu (2005) notably compare efficiency between banks from different types, including a few Islamic banks (the so-called "special finance houses”). They find no significant difference in efficiency between Islamic banks and other banks. Cihak and Hesse (2008) perform a comparative analysis of Islamic and conventional banks in terms of financial stability. They compare the Z-score, which is an inverse measure of the bank's probability of failure, for a sample of banks from 18 countries. They find that small Islamic banks are financially stronger than small conventional banks, but large conventional banks are financially stronger than large Islamic banks. Finally, Olson and Zoubi (2008) compare the accounting ratios of Islamic and conventional banks for the Gulf Cooperation Council countries. They notably conclude in favor of a greater profitability for Islamic banks.

The rest of the paper is organized as follows. Methodology is reported in section 2. Section 3 describes the data. The empirical results are shown in Section 4 . We finally provide some concluding remarks in section 5 .

\section{Methodology}

Empirical research on the measurement of bank competition provides several tools, which can be divided into the traditional Industrial Organization (IO) and the new empirical IO approaches. The traditional IO approach proposes tests of market structure to assess bank competition based on the Structure Conduct Performance (SCP) model. The SCP hypothesis 
argues that greater concentration causes less competitive bank conduct and leads to greater profitability of the bank. According to this, competition can be measured by concentration indices such as the market share of the largest banks, or by the Herfindahl index. These tools were widely applied until the 1990s.

The new empirical IO approach provides non-structural tests to circumvent the problems of the measures of competition provided by the traditional IO approach. These latter measures suffer from the fact that they infer the degree of competition from indirect proxies such as market structure or market shares. In comparison, non-structural measures do not infer the competitive conduct of banks through the analysis of market structure, but rather measure banks' conduct directly. The measures from the new empirical IO include the Rosse-Panzar model, which provide an aggregate measure of competition, and the Lerner index, an individual measure of market power.

In our work, we compute the Lerner index as we want to measure market power of each bank of our sample. The Lerner index has been computed in several recent studies on bank competition (e.g. Maudos and Fernandez de Guevara, 2004, 2007; Carbo et al., 2009). It is defined as the difference between the price and the marginal cost, divided by the price.

The price is computed by estimating the average price of bank production (proxied by total assets) as the ratio of total revenues to total assets, following Fernandez de Guevara, Maudos and Perez (2005) and Carbo et al. (2009) among others. The marginal cost is estimated on the basis of a translog cost function with one output (total assets) and three input prices (price of labor, price of physical capital, and price of borrowed funds). One cost function is estimated for each year to allow technology to change over time. Symmetry and linear homogeneity restrictions in input prices are imposed. The cost function is specified as follows:

$$
\ln T C=\alpha_{0}+\alpha_{1} \ln y+\frac{1}{2} \alpha_{2}(\ln y)^{2}+\sum_{j=1}^{3} \beta_{j} \ln w_{j}+\sum_{j=1}^{3} \sum_{k=1}^{3} \beta_{j k} \ln w_{j} \ln w_{k}+\sum_{j=1}^{3} \gamma_{j} \ln y \ln w_{j}+\varepsilon
$$

where TC denotes total costs, $y$ total assets, $w_{1}$ the price of labor (the ratio of personnel expenses to total assets) ${ }^{4}, w_{2}$ the price of physical capital (the ratio of other non-interest expenses to fixed assets), $w_{3}$ the price of borrowed funds (the ratio of interest expenses to all funding). Total costs are the sum of personnel expenses, other non-interest expenses and interest expenses. The indices for each bank have been dropped from the presentation for the

\footnotetext{
${ }^{4}$ As the Bankscope database does not provide information on the number of employees, we use this proxy variable for the price of labor following Maudos and Fernandez de Guevara (2004, 2007).
} 
sake of simplicity. The estimated coefficients of the cost function are then used to compute the marginal cost (MC) as follows:

$$
M C=\frac{T C}{y}\left(\alpha_{1}+\alpha_{2} \ln y+\sum_{j=1}^{3} \gamma_{j} \ln w_{j}\right)
$$

Once marginal cost has been estimated and price of output computed it is able to calculate the Lerner index for each bank and obtain a direct measure of bank competition.

\section{Data}

The sample used in this study includes the commercial, cooperative and savings banks of 17 countries (Bahrain, Bangladesh, Brunei, Indonesia, Iran, Jordan, Kuwait, Malaysia, Mauritania, Qatar, Saudi Arabia, Sudan, Tunisia, Turkey, United Arab Emirates, Yemen), in which Islamic banks and conventional banks coexist, over the period 2000-2007.

We use the Bankscope database to collect data from financial statements of the banks, in line with former cross-country studies including Islamic banks (Al-Muharrami, Matthews and Khabari, 2006; Viverita, Brown and Skully, 2007; Cihak and Hesse, 2008). We use unconsolidated accounting data of banks.

We adopt the Tukey box-plot, based on the use of interquartile range to clean data: banks with observations out of the range defined by the first and third quartiles that are greater or less than twice the interquartile range were dropped for each input price. We also perform some truncations for the Lerner indices. All outliers were dropped. These criteria produce a sample of 1301 observations for 264 banks, with 135 observations for 34 Islamic banks and 1166 observations for 230 conventional banks. The sample is described by country and by type of banks in table 1 .

Table 2 displays summary statistics for the variables adopted in the estimations. A striking observation is the similarities of both types of banks. No significant difference in bank size can be observed. The mean Islamic bank has 3.27 million USD of total assets to be compared to 3.78 million USD for the mean conventional bank. We also observe very similar mean input prices for labor and physical capital. The only difference concerns the price of borrowed funds which is greater for conventional banks (4.93\% vs. 3.50\% for Islamic banks). This dissimilarity can be relied to the observation of a greater equity to assets ratio for Islamic banks (14.72\% vs. $10.95 \%$ for conventional banks). Indeed, as Islamic banks rely more on 
equity, they may have lower charges on borrowed funds. Finally, we observe a major difference for activities with the analysis of the ratio of loans to investment assets, which is by far greater for conventional banks. This is in line with the different activities practiced by Islamic banks and conventional banks. Both these latter points suggest including the ratios of equity to assets and of loans to investment assets in the estimations explaining market power, as they constitute key differences between both types of banks.

\section{Results}

This section presents our results for the differences in market power between Islamic and conventional banks. We start with the Lerner indices for each type of bank. Next, we perform regressions of the Lerner index on a set of variables to take control variables into account. Finally, we perform a robustness check with an alternative measure of competition.

\section{IV.1 The market power measures}

We present the means of Lerner indices in table 3 for each type of bank and for each year. The average Lerner index for the period is $23.71 \%$ with yearly means ranging from $18.80 \%$ to $27.13 \%$. These figures are comparable to what is found in other studies. For instance, Fernandez de Guevara and Maudos (2007) find yearly mean Lerner indices between 16.9\% and 24.9\% for Spanish banks, while Carbo and al. (2009) observe mean Lerner indices at the country level ranging from $11 \%$ to $22 \%$ for EU countries with a EU mean of $16 \%$. In dynamic terms, the evolution of the Lerner index shows a strong increase between 2000 and 2005, followed by a reduction in market power between 2005 and 2007.

However the key issue concerns the comparison of market power between Islamic and conventional banks. The mean Lerner indices over the period are respectively $24.37 \%$ and 23.64\% for Islamic and conventional banks. But this difference in favor of Islamic banks is not systematic, as the analysis year-by-year shows that Islamic banks outperform conventional banks only for 4 years of our analysis while the opposite is observed for the 4 other years. Nonetheless the main finding is that the difference in market power is not significant either for each year considered separately or for the full period.

Thus, our major conclusion is the absence of significant difference in market power between Islamic banks and conventional banks. We do not support the arguments according to which Islamic banks would have greater market power. 
However this analysis has not considered the possible role of other characteristics of banks that differ between both types of banks. Furthermore, the fact that banks come from different countries should be taken into account. We therefore perform a regression of Lerner indices on a set of variables including the type of bank and several control variables.

\section{IV.2 Regression}

We perform a random effects GLS regression of the Lerner indices. This specification is motivated by the use of panel data, and the fact that the key explanatory variable, the fact that a bank is Islamic or not, is constant over time. The set of explanatory variables includes a dummy variable equal to one whether the bank is Islamic and zero else (Islam). We include three control variables in the regression: the ratio of loans to investment assets (Loans to Investment Assets) to take the mix of assets into account, the ratio of equity to total assets (Equity to Total Assets) to control for risk aversion, and size measured by the logarithm of total assets (Bank Size). We also include dummy variables for countries and years in the regression.

We now turn to the analysis of control variables. We observe a significantly positive sign for the size of the bank, which is in line with the fact that greater banks benefit from stronger market power. The ratio of loans to investment assets is not significant, meaning that the structure of assets between loans and investment assets does not exert an impact on market power. Finally, the ratio of equity to assets is significantly positive, according to which banks with greater solvency benefit from market power. This finding may be explained by the fact that better solvency allows the banks to charge greater prices to their services. Several papers have indeed shown the existence of market discipline among depositors, in particular in developing or transition countries in which the risk of bank failure is considered as important (e.g. Karas, Pyle and Schoors, 2009). This discipline means that depositors adapt their deposits to their perception of the probability of bank failure. Consequently, better solvency favors confidence of depositors in the bank's financial situation which can accept to pay more for this safety.

Therefore, our main finding is that Islamic banks do not have a greater market power than conventional banks. Our results from the regression even tend to show that Islamic banks have a lower market power.

Thus, we do not support the view that Islamic banks may benefit from a captive clientele owing to religious principles, which would be charged greater prices. How to explain 
the lower market power of Islamic banks? Several explanations can be advanced which focus either on the different religious or economic incentives of Islamic banks.

A first explanation may be the different objectives of Islamic banks in line with the distinguished values promoted in Islamic economics. Islamic finance is a part of a more global paradigm, Islamic economics, which can be defined as the economics in line with the principles of the Qur'an and the Sunna. While Islamic finance is the most well-known feature of Islamic economics, this discipline also includes other features as notably the promotion of Islamic norms of economic behavior.

Therefore, according to Hasan (2004), Islamic banks have different objectives than conventional banks in line with Islamic economics. Profit is also an objective for Islamic banks, as it is a survival requirement. Nevertheless these banks have other priorities, as Islam aims at establishing a distinct social order. The prohibition of interest is indeed not in itself the objective of Islamic banks, but rather an intermediary target through which Islamic banks contribute to establish a world in line with Islamic economics principles. A fundamental value to favor is the promotion of mutual help and cooperation. As a consequence, Kuran (2004) explains that a producer or a trader is free to seek personal profit, but he must avoid harming others. Therefore, he must charge fair prices to his customers. Thus, Islamic banks have the obligation to charge fair prices, which may limit their ability to charge the maximal price permitted by their degree of market power.

A big debate however exists in the literature about the practice of these specific norms in Islamic banks. Kuran (1995) observes similar returns on savings deposits for Islamic and conventional banks in Turkey, while El-Gamal (2007) provides examples of an Islamic bank explicitly mentioning that its loan rates are similar to those of conventional banks.

Some explanations can also be suggested which are based on the economic incentives for an Islamic bank to charge lower prices than other banks. Islamic banks may have greater incentives to avoid moral hazard behavior of borrowers, which gives them incentives to charge lower loan rates than conventional banks. The reasoning is based on the argument from Boyd and De Nicolo (2005). They pointed out the fact that lower loan rates make easier the repayment of loans, and consequently reduced the moral hazard behavior of borrowers to shift into riskier projects, which leads to lower default risk of borrowers. As a consequence, the more the bank suffers from moral hazard behavior of borrowers, the more the bank is inclined to charge lower rates. As Islamic banks follow the profit and loss sharing paradigm in opposition to conventional banks which charge fixed repayments, Islamic banks are more 
affected by moral hazard behavior as their return is riskier. They consequently have more incentives to avoid moral hazard behavior and then to charge lower rates.

Furthermore, we can also point out the fact than, on the deposit side, the depositors of Islamic banks are similar to shareholders as they do not have a fixed interest rate and share profits and losses of the bank. Consequently, greater profits from depositor services also mean higher prices charged for depositors for them. Thus, they may have incentives to refrain prices of financial services for depositors.

Finally, a last argument can also be advanced which is not guided by specific features of Islamic banking. As Islamic banking is a relatively recent industry, Islamic banks may be younger than conventional banks. However literature has shown the existence of switching costs in the banking industry. These costs notably derive from the time and effort to close an account or to become comfortable with a new bank (Kim, Kliger and Vale, 2003), or can also endogenously result from the better information of the bank on their clients than competitors (Sharpe, 1990; Rajan, 1992). As a consequence, as their establishment is more recent on average, Islamic banks may have a clientele less captive, which prevents them to have a similar market power than other banks.

\section{IV.3 A robustness check}

To further address the validity of the results, we use an alternative measure for bank competition in our estimations. We therefore estimate the Rosse-Panzar model (Rosse and Panzar, 1977), which has been widely applied in banking (e.g. Claessens and Laeven, 2004, for 50 countries; Al-Muharrami, Matthews and Khabari, 2006, for the six member countries of the Gulf Cooperation Council). It is a non-structural test, meaning that it takes into account the actual behavior of banks without using information on the structure of the banking market. The H-statistic aggregates the elasticities of total revenues to the input prices. It determines the nature of market structure: it is equal to 0 in monopoly, between 0 and 1 in monopolistic competition, and 1 in perfect competition.

Several recent studies aiming to explain banking competition have used the H-statistic as a measure of competition in regressions (Bikker and Haaf, 2002; Claessens and Laeven, 2004). We follow their approach by considering the H-statistic as a measure of competition, and aims to check the difference in the H-statistic between both types of banks.

Our aim is to have a measure of competition for each type of banks and each year. We therefore run the Rosse-Panzar model for year to obtain estimates of input prices which are specific to each year. Furthermore, as we need to have estimates of the coefficients of input 
prices specific to each type of banks, we include interactive terms for each input price, jointing the variable with a dummy variable for each type of bank. Consequently, we estimate the following equation for each year :

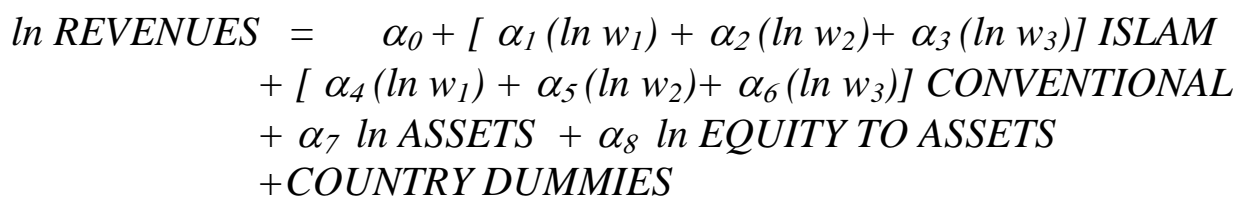

where REVENUES total revenues, $w_{1}, w_{2}$ and $w_{3}$ prices of labor, physical capital, and borrowed funds respectively which are defined below, ASSETS total assets, EQASS the ratio of equity to total assets, k country, ISLAM dummy variable equal to one whether the bank is Islamic, CONVENTIONAL dummy variable equal to one whether the bank is conventional. The variables ASSETS and EQUITY TO ASSETS take into account differences in size and risk respectively, akin to Bikker and Haaf (2002). Indices for each bank have been dropped in the presentation for simplicity. Therefore the $\mathrm{H}$-statistic is equal to $\alpha_{1}+\alpha_{2}+\alpha_{3}$ for Islamic banks and to $\alpha_{4}+\alpha_{5}+\alpha_{6}$ for conventional banks.

The results of the Rosse-Panzar model are shown in table 5 . We observe values between 0.3512 and 0.6233 for all types of banks and all years, meaning a monopolistic competition structure. This result is in accordance with most former studies estimating the Rosse-Panzar model (e.g. Bikker and Haaf, 2002). Al-Muharrami, Matthews and Khabari (2006) found a Hstatistic for the six countries of the Gulf Cooperation Council (Bahrain, Kuwait, Oman, Qatar, Saudi Arabia, United Arab Emirates) for 0.47 with country fixed effects and for 0.24 in a pooled model for the period 1993-2002. As a consequence, while our results are in line with the conclusion of monopolistic competition of this paper, we observe a greater competition level, which may result from the different sample of countries and also from a more recent period, suggesting an increase of competition.

However the key result is the fact that the H-statistic is greater for Islamic banks than for conventional banks for all years. This difference is only significant in 2005 and 2007. Therefore, the estimations of the Rosse-Panzar model tend to corroborate our main finding that Islamic banks are not less competitive than conventional banks. 


\section{Concluding remarks}

In this paper, we compare the market power of Islamic and conventional banks by computing Lerner indices for a large sample of banks from countries in which both types of banks coexist. Our hypothesis is that market power is greater for Islamic banks, in line with the view that these institutions benefit from clients with a more inelastic demand. This issue is of fundamental interest to understand the normative implications of the expansion of Iskamic banks. It has indeed been shown that lower bank competition may be detrimental to growth.

Our findings clearly reject this hypothesis. The comparison of Lerner indices shows not significant difference in market power between Islamic and conventional banks. Furthermore, the regression of market power indices even suggests a lower market power for Islamic banks.

We explain the lower market power of Islamic banks by their different religious and economic incentives. Indeed Islamic banks are supposed to respect some "Islamic" norms of behavior, such as the obligation to charge fair prices. This might consequently limit their ability to charge high prices. Furthermore, Islamic banks have incentives to charge lower loan rates than conventional banks, as they suffer more from the moral hazard behavior of borrowers which can be favored through high rates.

Thus, our conclusions do not provide support on some detrimental effects of the expansion of Islamic banks in terms of market power. Nevertheless the results of this study should be considered with care. Indeed this is the first contribution on this issue. Further work is therefore needed to confirm the findings and also to deepen the relevance of our interpretations. 


\section{References:}

1. Al-Muharrami, Saeed, Kent Matthews and Yusuf Khabari, 2006. "Market Structure and Competitive Conditions in the Arab GCC Banking System," Journal of Banking and Finance 30, 3487-3501.

2. Bikker Jakob and and Katharina Haaf, 2002. "Competition, Concentration and their Relationship: An Empirical Analysis of the Banking Industry", Journal of Banking and Finance 26, 2191-2214.

3. Boyd, John, and Gianni De Nicolo, 2005. "The Theory of Bank Risk Taking and Competition Revisited," Journal of Finance LX, 3, 1329-1343.

4. Carbo, Santiago, David Humphrey, Joaquin Maudos and Philip Molyneux, 2009. "Cross-Country Comparisons of Competition and Pricing Power in European Banking," Journal of International Money and Finance 28, 1, 115-134.

5. Cetorelli, Nicola and Michele Gambera, 2001. "Banking Market Structure, Financial Dependence and Growth : International Evidence from Industry Data," Journal of Finance 56, 617-648.

6. Chong, Beng Soon, and Ming-Hua Liu, 2009. "Islamic Banking: Interest-Free or Interest-Based ?," Pacific-Basin Finance Journal 17, 125-144.

7. Cihak, Martin and Heiko Hesse, 2008. "Islamic Banks and Financial Stability: An Empirical Analysis," IMF Working Papers 08/16.

8. Claessens, Stijn and Luc Laeven, 2004. "What Drives Bank Competition? Some International Evidence," Journal of Money, Credit and Banking 36, 3, 563-583.

9. El-Gamal, Mahmoud and Hulusi Inanoglu, 2005. "Inefficiency and Heterogeneity in Turkish Banking," Journal of Applied Econometrics 20, 641-664.

10. El-Gamal, Mahmoud, 2007. "Incoherence of Contract-Based Islamic Financial Jurisprudence in the Age of Financial Engineering," Rice University, mimeo.

11. Fernandez de Guevara, Juan, Joaquin Maudos and Francisco Perez, 2005. "Market Power in European Banking Sectors," Journal of Financial Services Research 27, 2, 109-137.

12. Fernandez de Guevara, Juan and Joaquin Maudos, 2007. "Explanatory Factors of Market Power in the Banking System," Manchester School 75, 3, 275-296.

13. Hasan, Zubair, 2004. "Measuring the Efficiency of Islamic Banks: Criteria, Methods and Social Priorities," Review of Islamic Economics 8, 2, 5-30.

14. Iqbal, Zamir and Abbas Mirakhor, 2007. An Introduction to Islamic Finance: Theory and Practice. Wiley.

15. Jayaratne, Jith and Philip Strahan, 1996. "The Finance-Growth Nexus : Evidence from Bank Branch Deregulation," Quarterly Journal of Economics 111, 639-670.

16. Karas, Alexei, William Pyle and Koen Schoors, 2009. "Sophisticated Discipline in a Nascent Deposit Market: Evidence from Post-Communist Russia," Oxford Economic Papers (forthcoming).

17. Kim, Moshe, Kliger, Doron, and Bent Vale B., 2003. "Estimating Switching Costs: The Case of Banking", Journal of Financial Intermediation 12, 1, 25-56.

18. Kuran, Timur, 1995. "Islamic Economics and the Islamic Subeconomy", Journal of Economic Perspectives 9, 155-173.

19. Kuran, Timur, 2004. Islam and Mammon, Princeton University Press.

20. Levine Ross, 2005. "Finance and Growth", in P. Aghion and S. Durlauf (eds.), Handbook of Economic Growth, Elsevier.

21. Maudos Joaquin and Juan Fernandez de Guevara, 2004. "Factors Explaining the Interest Margin in the Banking Sectors of the European Union," Journal of Banking and Finance 28, 2259-2281. 
22. Maudos, Joaquin and Juan Fernandez de Guevara, 2007. "The Cost of Market Power in Banking: Social Welfare Loss vs. Cost Inefficiency," Journal of Banking and Finance 31, 2103-2125.

23. Olson, Dennis and Taisier Zoubi, 2008. "Using Accounting Ratios to Distinguish between Islamic and Conventional banks in the GCC Region," International Journal of Accounting 43, 45-65.

24. Petersen, William and Raghuram Rajan, 1995. "The Effect of Credit Market Competition on Lending Relationships," Quarterly Journal of Economics 110, 407443.

25. Rajan, Raghuram, 1992. "Insiders and Outsiders: The Choice Between Informed and Arm's Length Debt," Journal of Finance 47, 1367-1400.

26. Rosse, John and James Panzar, 1977. "Chamberlin vs Robinson: An Empirical Study for Monopoly Rents," Bell Laboratories Economic Discussion Paper.

27. Sharpe, Steven, 1990. "Asymmetric Information, Bank Lending and Implicit Contracts: A Stylized Model of Customer Relationships", Journal of Finance, 10691087.

28. Solis, Liliana, and Joaquin Maudos, 2008. "The Social Costs of Bank Market Power: Evidence from Mexico," Journal of Comparative Economics 36, 3, 467-488.

29. Viverita, Kym Brown and Michael Skully, 2007. "Efficiency Analysis of Islamic Banks in Africa, Asia and the Middle East," Review of Islamic Economics 11, 2, 5-16. 
Table 1

Overview of the sample

This table gives the number of observations for each type of banks and for each country.

\begin{tabular}{lccc}
\hline Country & All banks & Conventional banks & Islamic banks \\
\hline Bahrain & 38 & 24 & 14 \\
Bangladesh & 222 & 218 & 4 \\
Brunei & 16 & 10 & 6 \\
Indonesia & 249 & 244 & 5 \\
Iran & 39 & 26 & 13 \\
Jordan & 45 & 30 & 15 \\
Kuwait & 39 & 32 & 7 \\
Malaysia & 170 & 158 & 12 \\
Mauritania & 26 & 19 & 7 \\
Pakistan & 158 & 148 & 10 \\
Qatar & 31 & 23 & 8 \\
Saudi Arabia & 28 & 24 & 4 \\
Sudan & 37 & 34 & 3 \\
Tunisia & 107 & 100 & 7 \\
Turkey & 38 & 32 & 6 \\
United Arab Emirates & 46 & 42 & 4 \\
Yemen & 12 & 2 & 10 \\
\hline All & 1301 & 1166 & 135 \\
\hline
\end{tabular}


Table 2

\section{Summary Statistics}

This table displays the means for variables used in subsequent estimations for each type of banks. Standard deviations are reported in brackets.

\begin{tabular}{lccc}
\hline & All banks & Conventional banks & Islamic banks \\
\hline Total assets (thd USD) & $3,719.65$ & $3,771.21$ & $3,274.30$ \\
& $(7,785.72)$ & $(7,930.48)$ & $(6,408.39)$ \\
Loans (thd USD) & $1,946.81$ & $1,936.93$ & $2,032.10$ \\
& $(3,992.48)$ & $(3,937.88)$ & $(4,451.36)$ \\
Price of labor (in \%) & 1.10 & 1.11 & 1.10 \\
& $(0.56)$ & $(0.57)$ & $(0.42)$ \\
Price of physical capital & 104.04 & 104.36 & 101.26 \\
(in \%) & $(77.78$ & $(77.89)$ & $(77.11)$ \\
Price of borrowed funds & 4.78 & 4.93 & 3.50 \\
(in \%) & $(2.71)$ & $(2.74)$ & $(2.06)$ \\
Loans to investment & 5.31 & 2.42 & 30.32 \\
assets & $(71.23)$ & $(4.59)$ & $(219.88)$ \\
Equity to assets & 11.34 & 10.95 & 14.72 \\
(in \%) & $(8.71)$ & $(8.47)$ & $(9.96)$ \\
\hline
\end{tabular}


Table 3

\section{Lerner indices}

This table presents the Lerner index for each year and for each type of banks. Lerner indices are presented in percentage. Standard deviations are displayed in brackets.

\begin{tabular}{lccccc}
\hline & All banks & $\begin{array}{c}\text { Conventional } \\
\text { banks }\end{array}$ & $\begin{array}{c}\text { Islamic } \\
\text { banks }\end{array}$ & Difference & p-value \\
\hline 2000 & 18.80 & 18.70 & 20.21 & -1.51 & 0.73 \\
2001 & $(13.28)$ & $(13.49)$ & $(10.56)$ & & 0.97 \\
& 19.66 & 19.65 & 19.79 & -0.14 & 0.93 \\
2002 & $(14.05)$ & $(14.39)$ & $(9.83)$ & & \\
& 21.62 & 21.65 & 21.29 & 0.36 & 0.20 \\
2003 & $(14.77)$ & $(15.09)$ & $(11.02)$ & & 0.17 \\
2004 & 24.83 & 25.35 & 19.99 & 5.36 & 0.43 \\
& $(16.34)$ & $(16.49)$ & $(14.47)$ & & \\
2005 & 26.87 & 27.53 & 22.10 & 5.43 & 0.12 \\
& $(17.03)$ & $(16.80)$ & $(18.34)$ & & \\
2006 & 27.13 & 26.78 & 30.07 & -3.28 & 0.63 \\
& $(16.65)$ & $(16.60)$ & $(17.28)$ & & \\
2007 & 25.38 & 24.64 & 30.07 & -5.43 & 0.61 \\
& $(15.68)$ & $(14.78)$ & $(20.28)$ & & \\
\hline All & 23.78 & 23.55 & 25.35 & -1.79 & \\
& $(15.40)$ & $(14.62)$ & $(20.28)$ & & \\
\hline
\end{tabular}




\section{Table 4}

\section{Regression}

Random effects GLS regression. The dependent variable is the Lerner index. *, **, *** denote an estimate significantly different from 0 at the $10 \%, 5 \%$ or $1 \%$ level. Dummy variables for countries and for years are included in the regression but are not reported.

\begin{tabular}{lcc}
\hline Explanatory variables & Coefficient & Standard error \\
\hline Intercept & -11.342 & 7.511 \\
Islamic Dummy & $-4.504^{*}$ & 2.547 \\
Bank Size & $2.515^{* * *}$ & 0.414 \\
Loans to Investment Assets & 0.002 & 0.006 \\
& & \\
Equity to Assets & $71.133^{* * *}$ & 5.752 \\
$\mathrm{R}^{2}$ & 0.3333 & \\
Number of banks & 264 & \\
Number of observations & 1301 & \\
\hline
\end{tabular}




\section{Table 5}

\section{Robustness check: The Rosse-Panzar Model}

This table displays the H-statistic estimated by the Rosse-Panzar model for each year and each type of banks. We compute the Wald test (F-statistic) to test whether the H-statistic is significantly different for Islamic and for conventional banks. *, **, *** denote a F-statistic significantly different from 0 at the $10 \%, 5 \%$ or $1 \%$ level.

\begin{tabular}{lccc}
\hline & Conventional banks & Islamic banks & Wald test (F statistic) \\
\hline 2000 & 0.5145 & 0.5991 & 0.91 \\
2001 & 0.5473 & 0.6233 & 1.08 \\
2002 & 0.4755 & 0.5526 & 0.80 \\
2003 & 0.4003 & 0.4431 & 0.26 \\
2004 & 0.3512 & 0.4084 & 1.08 \\
2005 & 0.3573 & 0.4629 & $3.95^{* *}$ \\
2006 & 0.5271 & 0.5320 & 0.01 \\
2007 & 0.4008 & 0.5801 & $6.08^{* *}$ \\
\hline
\end{tabular}




\title{
Working Papers
}

\section{Laboratoire de Recherche en Gestion \& Economie}

\author{
D.R. $\mathrm{n}^{\circ} 1 \quad$ "Bertrand Oligopoly with decreasing returns to scale", J. Thépot, décembre 1993 \\ D.R. $n^{\circ} 2$ "Sur quelques méthodes d'estimation directe de la structure par terme des taux d'intérêt", P. Roger - N. \\ Rossiensky, janvier 1994 \\ D.R. $n^{\circ} 3$ "Towards a Monopoly Theory in a Managerial Perspective", J. Thépot, mai 1993 \\ D.R. $n^{\circ} 4 \quad$ "Bounded Rationality in Microeconomics", J. Thépot, mai 1993 \\ D.R. n 5 "Apprentissage Théorique et Expérience Professionnelle", J. Thépot, décembre 1993 \\ D.R. $n^{\circ} 6 \quad$ "Strategic Consumers in a Duable-Goods Monopoly", J. Thépot, avril 1994 \\ D.R. $n^{\circ} 7 \quad$ "Vendre ou louer; un apport de la théorie des jeux", J. Thépot, avril 1994 \\ D.R. $\mathrm{n}^{\circ} 8$ \\ "Default Risk Insurance and Incomplete Markets", Ph. Artzner - FF. Delbaen, juin 1994 \\ D.R. $n^{\circ} 9$ \\ "Les actions à réinvestissement optionnel du dividende", C. Marie-Jeanne - P. Roger, janvier 1995 \\ D.R. $\mathrm{n}^{\circ} 10$ \\ "Forme optimale des contrats d'assurance en présence de coûts administratifs pour l'assureur", S. Spaeter, \\ février 1995
}

D.R. $\mathrm{n}^{\circ} 11$

D.R. $n^{\circ} 12$

"Une procédure de codage numérique des articles", J. Jeunet, février 1995

"Stabilité d'un diagnostic concurrentiel fondé sur une approche markovienne du comportement de rachat du consommateur", N. Schall, octobre 1995

D.R. $n^{\circ} 13 \quad$ "A direct proof of the coase conjecture", J. Thépot, octobre 1995

D.R. n $14 \quad$ "Invitation à la stratégie", J. Thépot, décembre 1995

D.R. $\mathrm{n}^{\circ} 15 \quad$ "Charity and economic efficiency", J. Thépot, mai 1996

D.R. n $16 \quad$ "Pricing anomalies in financial markets and non linear pricing rules", P. Roger, mars 1996

D.R. $n^{\circ} 17$ "Non linéarité des coûts de l'assureur, comportement de prudence de l'assuré et contrats optimaux", S. Spaeter, avril 1996

D.R. $\mathrm{n}^{\circ} 18$ "La valeur ajoutée d'un partage de risque et l'optimum de Pareto : une note", L. Eeckhoudt - P. Roger, juin 1996

D.R. n 19 "Evaluation of Lot-Sizing Techniques : A robustess and Cost Effectiveness Analysis", J. Jeunet, mars 1996

D.R. $\mathrm{n}^{\circ} 20 \quad$ "Entry accommodation with idle capacity", J. Thépot, septembre 1996 
D.R. $\mathrm{n}^{\circ} 21$ "Différences culturelles et satisfaction des vendeurs : Une comparaison internationale", E. VauquoisMathevet - J.Cl. Usunier, novembre 1996

D.R. n²2 "Evaluation des obligations convertibles et options d'échange", Schmitt - F. Home, décembre 1996

D.R n 23 "Réduction d'un programme d'optimisation globale des coûts et diminution du temps de calcul, J. Jeunet, décembre 1996

D.R. n 24 "Incertitude, vérifiabilité et observabilité : Une relecture de la théorie de l'agence", J. Thépot, janvier 1997

D.R. $\mathrm{n}^{\circ} 25 \quad$ "Financement par augmentation de capital avec asymétrie d'information : l'apport du paiement du dividende en actions", C. Marie-Jeanne, février 1997

D.R. n²6 "Paiement du dividende en actions et théorie du signal", C. Marie-Jeanne, février 1997

D.R. $n^{\circ} 27 \quad$ "Risk aversion and the bid-ask spread", L. Eeckhoudt - P. Roger, avril 1997

D.R. $\mathrm{n}^{\circ} 28$ "De l'utilité de la contrainte d'assurance dans les modèles à un risque et à deux risques", S. Spaeter, septembre 1997

D.R. $n^{\circ} 29$ "Robustness and cost-effectiveness of lot-sizing techniques under revised demand forecasts", J. Jeunet, juillet 1997

D.R. $\mathrm{n}^{\circ} 30 \quad$ "Efficience du marché et comparaison de produits à l'aide des méthodes d'enveloppe (Data envelopment analysis)", S. Chabi, septembre 1997

D.R. n $31 \quad$ "Qualités de la main-d'œuvre et subventions à l'emploi : Approche microéconomique", J. Calaza - P. Roger, février 1998

D.R $\mathrm{n}^{\circ} 32$ "Probabilité de défaut et spread de taux : Etude empirique du marché français", M. Merli - P. Roger, février 1998

D.R. n 33 "Confiance et Performance : La thèse de Fukuyama", J.Cl. Usunier - P. Roger, avril 1998

D.R. $\mathrm{n}^{\circ} 34 \quad$ "Measuring the performance of lot-sizing techniques in uncertain environments", J. Jeunet - N. Jonard, janvier 1998

D.R. $\mathrm{n}^{\circ} 35$ "Mobilité et décison de consommation : premiers résultas dans un cadre monopolistique", Ph. Lapp, octobre 1998

D.R. $\mathrm{n}^{\circ} 36$ "Impact du paiement du dividende en actions sur le transfert de richesse et la dilution du bénéfice par action", C. Marie-Jeanne, octobre 1998

D.R. n $^{\circ} 37$ "Maximum resale-price-maintenance as Nash condition", J. Thépot, novembre 1998

D.R. $\mathrm{n}^{\circ} 38 \quad$ "Properties of bid and ask prices in the rank dependent expected utility model", P. Roger, décembre 1998

D.R. n 39 "Sur la structure par termes des spreads de défaut des obligations ", Maxime Merli / Patrick Roger, septembre 1998

D.R. $n^{\circ} 40 \quad$ "Le risque de défaut des obligations: un modèle de défaut temporaire de l'émetteur", Maxime Merli, octobre 1998

D.R. $n^{\circ} 41 \quad$ "The Economics of Doping in Sports", Nicolas Eber / Jacques Thépot, février 1999

D.R. $n^{\circ} 42 \quad$ "Solving large unconstrained multilevel lot-sizing problems using a hybrid genetic algorithm", Jully Jeunet, mars 1999

D.R n $43 \quad$ "Niveau général des taux et spreads de rendement", Maxime Merli, mars 1999 
D.R. $n^{\circ} 45$

D.R. $\mathrm{n}^{\circ} 46$

D.R. $n^{\circ} 47$

D.R. $\mathrm{n}^{\circ} 48$

D.R. $n^{\circ} 49$

D.R. $\mathrm{n}^{\circ} 50$

D.R. $\mathrm{n}^{\circ} 51$

D.R. $\mathrm{n}^{\circ} 52$

D.R. $\mathrm{n}^{\circ} 53$

D.R. $\mathrm{n}^{\circ} 54$

D.R. $\mathrm{n}^{\circ} 55$

D.R. $\mathrm{n}^{\circ} 56$

D.R. $n^{\circ} 57$

D.R. $\mathrm{n}^{\circ} 58$

D.R. $\mathrm{n}^{\circ} 59$

D.R. $n^{\circ} 60$

D.R. $\mathrm{n}^{\circ} 61$

D.R. $\mathrm{n}^{\circ} 62$

D.R. $n^{\circ} 63$

D.R. $\mathrm{n}^{\circ} 64$

D.R. $n^{\circ} 65$

D.R. $\mathrm{n}^{\circ} 66$

D.R. $n^{\circ} 67$

"Doping in Sport and Competition Design", Nicolas Eber / Jacques Thépot, septembre 1999

"Interactions dans les canaux de distribution", Jacques Thépot, novembre 1999

"What sort of balanced scorecard for hospital", Thierry Nobre, novembre 1999

"Le contrôle de gestion dans les PME", Thierry Nobre, mars 2000

"Stock timing using genetic algorithms", Jerzy Korczak - Patrick Roger, avril 2000

"On the long run risk in stocks : A west-side story", Patrick Roger, mai 2000

"Estimation des coûts de transaction sur un marché gouverné par les ordres : Le cas des composantes du CAC40", Laurent Deville, avril 2001

"Sur une mesure d'efficience relative dans la théorie du portefeuille de Markowitz", Patrick Roger / Maxime Merli, septembre 2001

"Impact de l'introduction du tracker Master Share CAC 40 sur la relation de parité call-put", Laurent Deville, mars 2002

"Market-making, inventories and martingale pricing", Patrick Roger / Christian At / Laurent Flochel, mai 2002

"Tarification au coût complet en concurrence imparfaite", Jean-Luc Netzer / Jacques Thépot, juillet 2002

"Is time-diversification efficient for a loss averse investor ?", Patrick Roger, janvier 2003

“Dégradations de notations du leader et effets de contagion", Maxime Merli / Alain Schatt, avril 2003

"Subjective evaluation, ambiguity and relational contracts", Brigitte Godbillon, juillet 2003

"A View of the European Union as an Evolving Country Portfolio", Pierre-Guillaume Méon / Laurent Weill, juillet 2003

“Can Mergers in Europe Help Banks Hedge Against Macroeconomic Risk ?”, Pierre-Guillaume Méon / Laurent Weill, septembre 2003

"Monetary policy in the presence of asymmetric wage indexation", Giuseppe Diana / Pierre-Guillaume Méon, juillet 2003

"Concurrence bancaire et taille des conventions de services", Corentine Le Roy, novembre 2003

"Le petit monde du CAC 40", Sylvie Chabi / Jérôme Maati

"Are Athletes Different? An Experimental Study Based on the Ultimatum Game", Nicolas Eber / Marc Willinger

"Le rôle de l'environnement réglementaire, légal et institutionnel dans la défaillance des banques : Le cas des pays émergents", Christophe Godlewski, janvier 2004

"Etude de la cohérence des ratings de banques avec la probabilité de défaillance bancaire dans les pays émergents", Christophe Godlewski, Mars 2004

"Le comportement des étudiants sur le marché du téléphone mobile : Inertie, captivité ou fidélité ?", Corentine Le Roy, Mai 2004

"Insurance and Financial Hedging of Oil Pollution Risks", André Schmitt / Sandrine Spaeter, September, 2004 
D.R. $n^{\circ} 68$ "On the Backwardness in Macroeconomic Performance of European Socialist Economies", Laurent Weill, September, 2004

D.R. $\mathrm{n}^{\circ} 69 \quad$ "Majority voting with stochastic preferences : The whims of a committee are smaller than the whims of its members", Pierre-Guillaume Méon, September, 2004

D.R. $\mathrm{n}^{\circ} 70 \quad$ "Modélisation de la prévision de défaillance de la banque : Une application aux banques des pays émergents", Christophe J. Godlewski, octobre 2004

D.R. $\mathrm{n}^{\circ} 71 \quad$ "Can bankruptcy law discriminate between heterogeneous firms when information is incomplete ? The case of legal sanctions", Régis Blazy, october 2004

D.R. $\mathrm{n}^{\circ} 72$ "La performance économique et financière des jeunes entreprises", Régis Blazy/Bertrand Chopard, octobre 2004

D.R. $\mathrm{n}^{\circ} 73 \quad$ "Ex Post Efficiency of bankruptcy procedures : A general normative framework", Régis Blazy / Bertrand Chopard, novembre 2004

D.R. $n^{\circ} 74 \quad$ "Full cost pricing and organizational structure", Jacques Thépot, décembre 2004

D.R. $\mathrm{n}^{\circ} 75 \quad$ "Prices as strategic substitutes in the Hotelling duopoly", Jacques Thépot, décembre 2004

D.R. $n^{\circ} 76$ "Réflexions sur l'extension récente de la statistique de prix et de production à la santé et à l'enseignement", Damien Broussolle, mars 2005

D. R. $n^{\circ} 77$ "Gestion du risque de crédit dans la banque : Information hard, information soft et manipulation", Brigitte Godbillon-Camus / Christophe J. Godlewski

D.R. $\mathrm{n}^{\circ} 78$

"Which Optimal Design For LLDAs", Marie Pfiffelmann

D.R. $n^{\circ} 79$

"Jensen and Meckling 30 years after : A game theoretic view", Jacques Thépot

D.R. $n^{\circ} 80$

D.R. $\mathrm{n}^{\circ} 81$

“Organisation artistique et dépendance à l'égard des ressources”, Odile Paulus, novembre 2006

"Does collateral help mitigate adverse selection ? A cross-country analysis", Laurent Weill -Christophe J. Godlewski, novembre 2006

D.R. $\mathrm{n}^{\circ} 82$

"Why do banks ask for collateral and which ones ?", Régis Blazy - Laurent Weill, décembre 2006

D.R. $n^{\circ} 83$

"The peace of work agreement : The emergence and enforcement of a swiss labour market institution", D. Broussolle, janvier 2006.

D.R. $\mathrm{n}^{\circ} 84$

"The new approach to international trade in services in view of services specificities : Economic and regulation issues", D. Broussolle, septembre 2006.

D.R. $n^{\circ} 85 \quad$ "Does the consciousness of the disposition effect increase the equity premium" ?, P. Roger, juin 2007

D.R. $\mathrm{n}^{\circ} 86 \quad$ "Les déterminants de la décision de syndication bancaire en France", Ch. J. Godlewski

D.R. n 87 "Syndicated loans in emerging markets", Ch. J. Godlewski / L. Weill, mars 2007

D.R. $n^{\circ} 88$ "Hawks and loves in segmented markets : A formal approach to competitive aggressiveness", Claude d'Aspremont / R. Dos Santos Ferreira / J. Thépot, mai 2007

D.R. $n^{\circ} 89$ "On the optimality of the full cost pricing", J. Thépot, février 2007

D.R. $n^{\circ} 90 \quad$ "SME's main bank choice and organizational structure : Evidence from France", H. El Hajj Chehade / L. Vigneron, octobre 2007 
D.R n` 91 “How to solve St Petersburg Paradox in Rank-Dependent Models" ?, M. Pfiffelmann, octobre 2007

D.R. $n^{\circ} 92 \quad$ "Full market opening in the postal services facing the social and territorial cohesion goal in France", D. Broussolle, novembre 2007

D.R. $\mathrm{n}^{\circ}$ 2008-01 A behavioural Approach to financial puzzles, M.H. Broihanne, M. Merli, P. Roger, janvier 2008

D.R. $\mathrm{n}^{\circ}$ 2008-02 What drives the arrangement timetable of bank loan syndication ?, Ch. J. Godlewski, février 2008

D.R. $n^{\circ}$ 2008-03 Financial intermediation and macroeconomic efficiency, Y. Kuhry, L. Weill, février 2008

D.R. $\mathrm{n}^{\circ}$ 2008-04 The effects of concentration on competition and efficiency : Some evidence from the french audit market, G. Broye, L. Weill, février 2008

D.R. $\mathrm{n}^{\circ} 2008-05$

Does financial intermediation matter for macroeconomic efficiency?, P.G. Méon, L. Weill, février 2008

D.R. $\mathrm{n}^{\circ} 2008-06$ Is corruption an efficient grease ?, P.G. Méon, L. Weill, février 2008

D.R. $n^{\circ} 2008-07$

Convergence in banking efficiency across european countries, L. Weill, février 2008

D.R. $\mathrm{n}^{\circ} 2008-08$

Banking environment, agency costs, and loan syndication : A cross-country analysis, Ch. J. Godlewski, mars 2008

D.R. $n^{\circ} 2008-09$

Are French individual investors reluctant to realize their losses ?, Sh. Boolell-Gunesh / M.H. Broihanne / M. Merli, avril 2008

D.R. $\mathrm{n}^{\circ} 2008-10$

Collateral and adverse selection in transition countries, Ch. J. Godlewski / L. Weill, avril 2008

D.R. $n^{\circ} 2008-11$

How many banks does it take to lend ? Empirical evidence from Europe, Ch. J. Godlewski, avril 2008.

D.R. $n^{\circ} 2008-12$

Un portrait de l'investisseur individuel français, Sh. Boolell-Gunesh, avril 2008

D.R. $\mathrm{n}^{\circ} 2008-13$

La déclaration de mission, une revue de la littérature, Odile Paulus, juin 2008

D.R. $n^{\circ} 2008-14$

Performance et risque des entreprises appartenant à des groupes de PME, Anaïs Hamelin, juin 2008

D.R. $n^{\circ} 2008-15$

Are private banks more efficient than public banks ? Evidence from Russia,

Alexei Karas / Koen Schoors / Laurent Weill, septembre 2008

D.R. $\mathrm{n}^{\circ} 2008-16$

Capital protected notes for loss averse investors : A counterintuitive result, Patrick Roger, septembre 2008

D.R. $n^{\circ} 2008-17$

Mixed risk aversion and preference for risk disaggregation, Patrick Roger, octobre 2008

D.R. $n^{\circ} 2008-18$

Que peut-on attendre de la directive services?, Damien Broussolle, octobre 2008

D.R. $n^{\circ} 2008-19$

Bank competition and collateral: Theory and Evidence, Christa Hainz / Laurent Weill / Christophe J. Godlewski, octobre 2008

D.R. $\mathrm{n}^{\circ} 2008-20$

Duration of syndication process and syndicate organization, Ch. J. Godlewski, novembre 2008

D.R. $\mathrm{n}^{\circ} 2008-21$

How corruption affects bank lending in Russia, L. Weill, novembre 2008

D.R. $n^{\circ} 2008-22$

On several economic consequences of the full market opening in the postal service in the European Union, D. Broussolle, novembre 2008. 
D.R. $n^{\circ} 2009-01$ Asymmetric Information and Loan Spreads in Russia: Evidence from Syndicated Loans, Z. Fungacova, C.J. Godlewski, L. Weill

D.R. $n^{\circ} 2009-02$

Do Islamic Banks Have Greater Market Power ?, L. Weill 